\title{
Effect of Temperature on Physical Properties of CNSL based Termiticides
}

\author{
Kamble K. J. ${ }^{1}$, N. J. Thakor ${ }^{2}$ \\ Department of Agricultural Process Engineering, Dr. ASCAET, MPKV, Rahuri, Dist. Ahmednagar
}

\begin{abstract}
Cashew nut shell liquid based termiticides using neemseed oil, karanjseed oil and bhilawan shell liquid, were developed and the effect of 30,60, 90 and $120^{\circ} \mathrm{C}$ temperatures on viscosity, refractive index, specific gravity and colour was studied. It was observed that viscosity and refractive index of termiticides decreased with heating temperature from 30 to 120 ${ }^{\circ} \mathrm{C}$, specific gravity found decreased with increase in temperature from 30,60 and $90^{\circ} \mathrm{C}$. Colour of Neemseed oil became bright yellow and of Cashew nut shell liquid, Karanjseed oil and Bhilawan shell liquid became darker when heated at temperature from 30 to $120^{\circ} \mathrm{C}$. CNSL based termiticides were oil based therefore the properties of oils were reflected in the termiticide formulations with respect to the temperature.
\end{abstract}

Keywords—Cashew nut shell, Termiticides, neemseed oil, karanjseed oil, bhilawan shell liquid.

\section{INTRODUCTION}

Use of chemicals for termite control is in huge quantity world over which adds in the problems of biotic and abiotic factors in the environment. Plant oils in the nature having termiticidal properties can be safer, cheaper and easily available alternative to the hazardous chemical termiticides in the market. Various plants like Cashew nut (Anacardium occidental), Neem (Azadirachta indica), Karanj (Pongamia pinnata) and Bhilawa or Markingnut (Semecarpus anacardium Linn.) have been found to have termiticidal properties. These trees are abundantly available in coastal and semi-arid regions of India and the world. Therefore, cashew nut shell liquid(CNSL), neemseed oil(NSO), karanjseed oil(KSO) and bhilawan shell liquid(BSL) were used to develop CNSL based termiticides to reduce the use of hazardous chemicals in agriculture as pesticides in general and for termite control in special. Sixteen formulations of CNSL $(100,80,70,60,50 \%)$, NSO $(10,15,20,25,100 \%)$, KSO $(10,15,20,25,100 \%)$ and BSL $(10,15,20,25,100 \%)$ were made to develop CNSL based termiticide. The influence of atmospheric temperature on physicochemical properties of oils used in the study may affect the mixing of oils, forming uniform coat on the surface of wood samples and absorption of solution by wood samples when dipped in it. Hence effect of temperature on viscosity, refractive index, specific gravity and colour of CNSL based termiticides was studied. This study was conducted in the laboratories of Dept. of Agricultural Process Engineering., Dept. of Electrical and Other Energy Sources; and Dept. of Soil Science and Agricultural Chemistry, Dr. BSKKV, Dapoli, Dept. of Petrochemical Engineering in Dr. Babasaheb Ambedkar Technical University, Lonere, Dist. Raigad and Insta Pollutech Lab, Pune.

\section{MATERIALS AND METHODS}

Cashew Nut Shell Liquid was procured from Shri. Uma Industries, Plot. No. D-48, Addl. MIDC Kudal, At. Po. NerurWaghchaudi, Dsit. Sindhudurga- 416520. Neemseed oil was procured from Biocrop Agro Industries, 594/4, Shiroli MIDC, Kolhapur- 416122. Karanjseed oil was procured from Vijaya Agro Industries, Plot No. 136, A- Section Sangamner Co-Op. Industrial Estate, Ta. Sangamner, Dist. Ahmednagar- 02425-222415. Bhilawan Shell Liquid was procured from Shri. Hanmant Einathrao Kausalle, At. Po. Chincholi, Ta. Kandhar, Dist. Nanded. These were the tree born oils obtained directly from the source of production and were used in the study.

Cashew nut shell liquid based termiticides were developed by using NSO, KSO and BSL at different levels, mixed in CNSL as shown in Table 1. Two oils each time among NSO, KSO and BSL were mixed in CNSL to make up of the total of formulation $100 \%$. The levels of first four formulations $\mathrm{TO}_{1}, \mathrm{TO}_{2}, \mathrm{TO}_{3}$ and $\mathrm{TO}_{4}$ were $100 \%$ of CNSL, NSO, KSO and BSL, respectively. In the next twelve formulations from $\mathrm{TO}_{5}$ to $\mathrm{TO}_{16}$, the levels of CNSL were 100, 80, 70, 60, 50\%; and of NSO, KSO and BSL were $10,15,20$ and $25 \%$ each.

Effect of temperature on viscosity, refractive index, specific gravity and colour of CNSL based termiticides was studied by following standard procedures and methods as shown in Table 2. 
TABLE 1

CNSL BASED OIL FORMULATED TERMITICIDES

\begin{tabular}{|c|c|c|c|c|c|}
\hline \multirow{2}{*}{ No. } & \multirow{2}{*}{ Treatment } & \multicolumn{4}{|c|}{ Oils } \\
\hline & & CNSL $(\%)$ & NSO $(\%)$ & KSO (\%) & BSL (\%) \\
\hline 1 & $\mathrm{TO}_{1}$ & 100 & 0 & 0 & 0 \\
\hline 2 & $\mathrm{TO}_{2}$ & 0 & 100 & 0 & 0 \\
\hline 3 & $\mathrm{TO}_{3}$ & 0 & 0 & 100 & 0 \\
\hline 4 & $\mathrm{TO}_{4}$ & 0 & 0 & 0 & 100 \\
\hline 5 & $\mathrm{TO}_{5}$ & 80 & 10 & 10 & 0 \\
\hline 6 & $\mathrm{TO}_{6}$ & 80 & 10 & 0 & 10 \\
\hline 7 & $\mathrm{TO}_{7}$ & 80 & 0 & 10 & 10 \\
\hline 8 & $\mathrm{TO}_{8}$ & 70 & 15 & 15 & 0 \\
\hline 9 & $\mathrm{TO}_{9}$ & 70 & 15 & 0 & 15 \\
\hline 10 & $\mathrm{TO}_{10}$ & 70 & 0 & 15 & 15 \\
\hline 11 & $\mathrm{TO}_{11}$ & 60 & 20 & 20 & 0 \\
\hline 12 & $\mathrm{TO}_{12}$ & 60 & 20 & 0 & 20 \\
\hline 13 & $\mathrm{TO}_{13}$ & 60 & 0 & 20 & 20 \\
\hline 14 & $\mathrm{TO}_{14}$ & 50 & 25 & 25 & 0 \\
\hline 15 & $\mathrm{TO}_{15}$ & 50 & 25 & 0 & 25 \\
\hline 16 & $\mathrm{TO}_{16}$ & 50 & 0 & 25 & 25 \\
\hline 17 & $\mathrm{TO}_{17}($ Control $)$ & 0 & 0 & 0 & 0 \\
\hline
\end{tabular}

(TO- Treatment of oil formulation, CNSL-Cashew nut shell liquid, NSO- Neemseed oil, KSO-Karanjseed oil, BSL-Bhilawan shell liquid)

TABLE 2

METHODS USED FOR DETERMINATION OF PROPERTIES OF CNSL BASED TERMITICIDES

\begin{tabular}{|c|c|c|}
\hline Sr. No. & Property & Method \\
\hline 1 & Viscosity & ISO 2555:1989 \\
\hline 2 & Refractive Index & AOAC, 2000 \\
\hline 3 & Specific Gravity & AOAC, 2000 \\
\hline 4 & Colour & I.S. 548(Part 1) - 1964 \\
\hline
\end{tabular}

\subsection{Viscosity}

Viscosity is a measure of resistance to flow of a fluid. Although molecules of a fluid are in constant random motion, the velocity in a particular direction is zero unless some force is applied to cause fluid to flow. The magnitude of the force needed to induce flow at a certain velocity is related to the viscosity of a fluid. Viscosity of CNSL based termiticides $\left(\mathrm{T}_{1}\right.$. $\mathrm{TO}_{16}$ ) was determined at temperatures 30,60, 90 and $120{ }^{\circ} \mathrm{C}$ by using Brookfield Viscometer as per the 'ISO 2555:1989' in the laboratory of the Department of Agricultural Process Engineering, Dr. Annasaheb Shinde College of Agricultural Engineering \& Technology, MPKV, Rahuri and results are given in the Table 3.

\subsection{Refractive Index}

The ratio of velocity of light in vacuum to the velocity of light in the oil or fat; more generally, it expresses the ratio between the sine of angle of incidence to the sine of angle of refraction, when a ray of light of known wave length (usually $589.3 \mathrm{~nm}$, the mean of $\mathrm{D}$ lines of sodium) passes from air into the oil or fat. Effect of temperature on refractive index of CNSL based termiticides $\mathrm{TO}_{1}$ to $\mathrm{TO}_{16}$ was studied at temperatures $30,60,90$ and $120{ }^{\circ} \mathrm{C}$ as per the 'AOAC 2000 ' in the National Agricultural Innovative Programme Laboratory, CAET, Dr. BSKKV, Dapoli by using Refractometer and results are given in the Table 4. 
TABLE 3

EFFECT OF TEMPERATURE ON VISCOSITY OF CNSL BASED TERMITICIDES

\begin{tabular}{|c|c|c|c|c|c|c|c|}
\hline \multirow{3}{*}{$\begin{array}{l}\text { Sr. } \\
\text { No. }\end{array}$} & \multirow{3}{*}{ Treatment } & \multirow{3}{*}{$\begin{array}{c}\text { Formulation } \\
\text { CNSL:NSO:KSO:BSL }\end{array}$} & \multirow{2}{*}{\multicolumn{4}{|c|}{$\frac{\text { Viscosity }(\mathbf{c P})}{\text { Temperature }\left({ }^{0} \mathrm{C}\right)}$}} & \multirow{3}{*}{ Response to temperature (\%) } \\
\hline & & & & & & & \\
\hline & & & 30 & 60 & 90 & 120 & \\
\hline 1 & $\mathrm{TO}_{1}$ & 100:0:0:0 & 562 & 475 & 448 & 395 & 29.72 \\
\hline 2 & $\mathrm{TO}_{2}$ & 0:100:0:0 & 89 & 20 & 10 & 5 & 94.38 \\
\hline 3 & $\mathrm{TO}_{3}$ & 0:0:100:0 & 32 & 12 & 6 & 4 & 87.50 \\
\hline 4 & $\mathrm{TO}_{4}$ & 0:0:0:100 & 1070 & 890 & 650 & 422 & 60.56 \\
\hline 5 & $\mathrm{TO}_{5}$ & $80: 10: 10: 0$ & 462 & 449 & 343 & 321 & 30.52 \\
\hline 6 & $\mathrm{TO}_{6}$ & $80: 10: 0: 10$ & 673 & 645 & 489 & 437 & 35.07 \\
\hline 7 & $\mathrm{TO}_{7}$ & $80: 0: 10: 10$ & 667 & 621 & 467 & 405 & 39.28 \\
\hline 8 & $\mathrm{TO}_{8}$ & $70: 15: 15: 0$ & 411 & 385 & 352 & 318 & 22.63 \\
\hline 9 & $\mathrm{TO}_{9}$ & $70: 15: 0: 15$ & 727 & 679 & 438 & 410 & 43.60 \\
\hline 10 & $\mathrm{TO}_{10}$ & $70: 0: 15: 15$ & 719 & 688 & 413 & 391 & 45.62 \\
\hline 11 & $\mathrm{TO}_{11}$ & $60: 20: 20: 0$ & 361 & 344 & 310 & 296 & 18.01 \\
\hline 12 & $\mathrm{TO}_{12}$ & 60:20:0:20 & 783 & 721 & 474 & 419 & 46.49 \\
\hline 13 & $\mathrm{TO}_{13}$ & $60: 0: 20: 20$ & 771 & 705 & 458 & 401 & 47.99 \\
\hline 14 & $\mathrm{TO}_{14}$ & 50:25:25:0 & 311 & 293 & 267 & 234 & 24.76 \\
\hline 15 & $\mathrm{TO}_{15}$ & $50: 25: 0: 25$ & 838 & 782 & 539 & 495 & 40.93 \\
\hline 16 & $\mathrm{TO}_{16}$ & $50: 0: 25: 25$ & 824 & 781 & 516 & 473 & 42.60 \\
\hline
\end{tabular}

(TO-Oil Formulation Treatment, CNSL-Cashew nut shell liquid, NSO- Neemseed oil, KSO- Karanjseed oil, BSL-Bhilawan shell liquid)

TABLE 4

EFFECT OF TEMPERATURE ON REFRACTIVE INDEX OF CNSL BASED TERMITICIDES

\begin{tabular}{|c|c|c|c|c|c|c|c|}
\hline \multirow{3}{*}{$\begin{array}{l}\text { Sr. } \\
\text { No. }\end{array}$} & \multirow{3}{*}{ Treatment } & & \multicolumn{4}{|c|}{ Refractive Index } & \multirow{3}{*}{$\begin{array}{c}\text { Response to } \\
\text { temperature }(\%)\end{array}$} \\
\hline & & & \multicolumn{4}{|c|}{ Temperatures $\left({ }^{\circ} \mathbf{C}\right)$} & \\
\hline & & CNSL : NO : KO : BSL & 30 & 60 & 90 & 120 & \\
\hline 1 & $\mathrm{TO}_{1}$ & 100:0:0:0 & 1.512 & 1.508 & 1.486 & 1.471 & 2.71 \\
\hline 2 & $\mathrm{TO}_{2}$ & 0:100:0:0 & 1.471 & 1.462 & 1.448 & 1.443 & 1.90 \\
\hline 3 & $\mathrm{TO}_{3}$ & 0:0:100:0 & 1.423 & 1.411 & 1.406 & 1.391 & 2.25 \\
\hline 4 & $\mathrm{TO}_{4}$ & 0:0:0:100 & 1.526 & 1.510 & 1.504 & 1.489 & 2.42 \\
\hline 5 & $\mathrm{TO}_{5}$ & 80:10:10:0 & 1.499 & 1.494 & 1.49 & 1.459 & 2.67 \\
\hline 6 & $\mathrm{TO}_{6}$ & 80:10:0:10 & 1.510 & 1.504 & 1.499 & 1.469 & 2.72 \\
\hline 7 & $\mathrm{TO}_{7}$ & $80: 0: 10: 10$ & 1.505 & 1.499 & 1.495 & 1.464 & 2.72 \\
\hline 8 & $\mathrm{TO}_{8}$ & 70:15:15:0 & 1.491 & 1.486 & 1.481 & 1.453 & 2.55 \\
\hline 9 & $\mathrm{TO}_{9}$ & $70: 15: 0: 15$ & 1.507 & 1.501 & 1.495 & 1.468 & 2.59 \\
\hline 10 & $\mathrm{TO}_{10}$ & $70: 0: 15: 15$ & 1.500 & 1.494 & 1.489 & 1.46 & 2.67 \\
\hline 11 & $\mathrm{TO}_{11}$ & $60: 20: 20: 0$ & 1.496 & 1.479 & 1.473 & 1.448 & 3.21 \\
\hline 12 & $\mathrm{TO}_{12}$ & 60:20:0:20 & 1.506 & 1.499 & 1.493 & 1.467 & 2.59 \\
\hline 13 & $\mathrm{TO}_{13}$ & $60: 0: 20: 20$ & 1.507 & 1.489 & 1.485 & 1.457 & 3.32 \\
\hline 14 & $\mathrm{TO}_{14}$ & $50: 25: 25: 0$ & 1.479 & 1.472 & 1.465 & 1.814 & 3.04 \\
\hline 15 & $\mathrm{TO}_{15}$ & $50: 25: 0: 25$ & 1.505 & 1.497 & 1.49 & 1.467 & 2.52 \\
\hline 16 & $\mathrm{TO}_{16}$ & $50: 0: 25: 25$ & 1.492 & 1.483 & 1.479 & 1.454 & 2.55 \\
\hline
\end{tabular}

(TO-Oil Formulation Treatment, CNSL-Cashew nut shell liquid, NSO- Neemseed oil, KSO- Karanjseed oil, BSL-Bhilawan shell liquid) 


\subsection{Specific Gravity}

Specific gravity is the ratio of weight of termiticide at $30{ }^{\circ} \mathrm{C}$ to the weight of water at $30{ }^{\circ} \mathrm{C}$. Specific gravity of CNSL based termiticides $\mathrm{TO}_{1}$ to $\mathrm{TO}_{16}$ was determined at different temperatures 30,60 and $90{ }^{\circ} \mathrm{C}$, as per the "AOAC, 2000 in the laboratory of Soil Science and Agricultural Chemistry, College of Agriculture, Dr. BSKKV, Dapoli by the formula given below

$$
\text { Specific gravity of termiticide at } 30{ }^{\circ} \mathrm{C}=\frac{\mathrm{A}-\mathrm{B}}{\mathrm{C}-\mathrm{D}}
$$

Where,

$$
\begin{aligned}
& \mathrm{A}=\text { weight in gm of specific gravity bottle with termiticide at } 30{ }^{\circ} \mathrm{C} \\
& \mathrm{B}=\text { weight in gm of specific gravity bottle at } 30^{\circ} \mathrm{C} \\
& \mathrm{C}=\text { weight in gm of specific gravity bottle with water at } 30{ }^{\circ} \mathrm{C}
\end{aligned}
$$

\begin{tabular}{|c|c|c|c|c|c|c|}
\hline \multirow{3}{*}{$\begin{array}{l}\text { Sr. } \\
\text { No. }\end{array}$} & \multirow{3}{*}{ Treatment } & \multirow{2}{*}{ Formulation } & \multicolumn{3}{|c|}{ Specific Gravity } & \multirow{3}{*}{$\begin{array}{l}\text { Response to } \\
\text { temperature } \\
(\%)\end{array}$} \\
\hline & & & \multicolumn{3}{|c|}{ Temperature $\left({ }^{\circ} \mathbf{C}\right)$} & \\
\hline & & CNSL : NO : KO : BSL & 30 & 60 & 90 & \\
\hline 1 & $\mathrm{TO}_{1}$ & 100:0:0:0 & 0.948 & 0.942 & 0.939 & 0.94 \\
\hline 2 & $\mathrm{TO}_{2}$ & 0:100:0:0 & 0.938 & 0.937 & 0.933 & 0.50 \\
\hline 3 & $\mathrm{TO}_{3}$ & 0:0:100:0 & 0.933 & 0.932 & 0.932 & 0.03 \\
\hline 4 & $\mathrm{TO}_{4}$ & 0:0:0:100 & 0.987 & 0.985 & 0.983 & 0.40 \\
\hline 5 & $\mathrm{TO}_{5}$ & 80:10:10:0 & 0.950 & 0.940 & 0.930 & 1.54 \\
\hline 6 & $\mathrm{TO}_{6}$ & 80:10:0:10 & 0.960 & 0.950 & 0.930 & 3.43 \\
\hline 7 & $\mathrm{TO}_{7}$ & 80:0:10:10 & 0.950 & 0.930 & 0.910 & 3.51 \\
\hline 8 & $\mathrm{TO}_{8}$ & $70: 15: 15: 0$ & 0.950 & 0.940 & 0.920 & 2.91 \\
\hline 9 & $\mathrm{TO}_{9}$ & $70: 15: 0: 15$ & 0.960 & 0.940 & 0.940 & 2.45 \\
\hline 10 & $\mathrm{TO}_{10}$ & $70: 0: 15: 15$ & 0.950 & 0.940 & 0.92 & 3.78 \\
\hline 11 & $\mathrm{TO}_{11}$ & 60:20:20:0 & 0.950 & 0.930 & 0.91 & 3.51 \\
\hline 12 & $\mathrm{TO}_{12}$ & $60: 20: 0: 20$ & 0.950 & 0.940 & 0.920 & 3.40 \\
\hline 13 & $\mathrm{TO}_{13}$ & $60: 0: 20: 20$ & 0.950 & 0.940 & 0.910 & 4.88 \\
\hline 14 & $\mathrm{TO}_{14}$ & $50: 25: 25: 0$ & 0.940 & 0.920 & 0.910 & 3.72 \\
\hline 15 & $\mathrm{TO}_{15}$ & $50: 25: 0: 25$ & 0.970 & 0.950 & 0.930 & 3.21 \\
\hline 16 & $\mathrm{TO}_{16}$ & $50: 0: 25: 25$ & 0.960 & 0.950 & 0.930 & 3.95 \\
\hline
\end{tabular}

Results of specific gravity are shown in the Table 5.

TABLE 5

EFFECT OF TEMPERATURE ON SPECIFIC GRAVITY OF CNSL BASED TERMITICIDES

(TO-Oil Formulation Treatment, CNSL-Cashew nut shell liquid, NSO- Neemseed oil, KSO- Karanjseed oil, BSL-Bhilawan shell liquid)

\subsection{Colour}

The colour ( $\mathrm{L}^{*}, \mathrm{a}^{*}$ and $\mathrm{b}^{*}$ values) of CNSL based termiticides $\mathrm{TO}_{1}$ to $\mathrm{TO}_{16}$ was determined by using Colour Flex Meter. $\mathrm{L}^{*}$ indicates the lightness and extends from 0 (black) to 100 (white). The other two coordinates $a^{*}$ and $b^{*}$ indicate redness (+a) to greenness (-a) and yellowness (+b) to blueness (-b), respectively. The colour is expressed as the sum total of the yellow and red slides used to match the colour of the specimen oil sample. Colour of CNSL based termiticides was determined at temperatures 30, 60, 90 and $120^{\circ} \mathrm{C}$, by Colour Flex Meter in the laboratory of the Department of Agricultural Process Engineering, Dr. Annasaheb Shinde College of Agricultural Engineering \& Technology, MPKV, Rahuri as per the 'I.S. 548(part 1)-1964' and results are given in the Table 6. 
TABLE 6

EFFECT OF TEMPERATURE ON COLOUR OF CNSL BASED TERMITICIDES

\begin{tabular}{|c|c|c|c|c|c|c|c|c|c|c|c|c|c|}
\hline \multirow[t]{2}{*}{ Treatment } & \multirow{2}{*}{$\begin{array}{c}\text { Formulation } \\
\text { CNSL:NSO: } \\
\text { KSO:BSL }\end{array}$} & \multicolumn{3}{|c|}{$\begin{array}{l}\text { Colour difference } \\
\text { values at } 30^{\circ} \mathrm{C}\end{array}$} & \multicolumn{3}{|c|}{$\begin{array}{l}\text { Colour difference } \\
\text { values at } 60^{\circ} \mathrm{C}\end{array}$} & \multicolumn{3}{|c|}{$\begin{array}{l}\text { Colour difference } \\
\text { values at } 90^{\circ} \mathrm{C}\end{array}$} & \multicolumn{3}{|c|}{$\begin{array}{c}\text { Colour difference } \\
\text { values at } 120^{\circ} \mathrm{C}\end{array}$} \\
\hline & & DL* & $\mathrm{Da}^{*}$ & $\mathrm{Db}^{*}$ & DL* & Da* & $\mathrm{Db}^{*}$ & DL* & Da* & Db* & DL* & Da* & $\mathrm{Db}^{*}$ \\
\hline $\mathrm{TO}_{1}$ & 100:0:0:0 & -72.49 & 0.85 & -2.26 & -72.40 & 0.72 & -2.15 & -72.59 & 0.52 & -2.18 & -73.14 & 0.91 & -2.59 \\
\hline $\mathrm{TO}_{2}$ & $0: 100: 0: 0$ & -71.26 & 1.48 & 0.08 & -71.34 & 2.52 & 0.15 & -71.50 & 1.74 & -0.12 & -72.53 & 5.70 & 1.11 \\
\hline $\mathrm{TO}_{3}$ & & -63.1 & 11.65 & 13.06 & $\begin{array}{l}-60.67 \\
\end{array}$ & 10.13 & 17.01 & -58.74 & 9.44 & 19.68 & -68.61 & 10.75 & 13.47 \\
\hline $\mathrm{TO}_{4}$ & $0: 0: 0: 100$ & -72.36 & 0.44 & -2.35 & $\begin{array}{l}-72.79 \\
\end{array}$ & 0.46 & -2.31 & -72.53 & 0.49 & -2.35 & -73.09 & 0.59 & -2.57 \\
\hline $\mathrm{TO}_{5}$ & $80 \cdot 10 \cdot 1$ & -73.36 & 1.13 & -1.94 & -72.93 & 1.19 & -2.06 & -73.52 & 1.48 & -2.04 & -73.25 & 1.58 & -2.01 \\
\hline $\mathrm{TO}_{6}$ & 10 & -73.39 & 0.84 & -1.76 & -73.38 & 0.69 & -1.34 & -73.35 & 0.68 & -1.75 & -73.40 & 1.43 & -2.46 \\
\hline $\mathrm{TO}_{7}$ & & -72.94 & 1.47 & -2.10 & -72.95 & 1.27 & -2.26 & -72.73 & 1.91 & -2.50 & -72.46 & 1.81 & -2.70 \\
\hline $\mathrm{TO}_{8}$ & & -72.29 & $0.4 \varepsilon$ & -2.55 & -72.42 & 0.4 & -2.88 & -72.43 & 0.29 & -2.93 & -72.60 & 0.86 & -3.16 \\
\hline $\mathrm{TO}_{9}$ & & -71.99 & 0.8 & -3.33 & -72.19 & 0.81 & -3.11 & -72.17 & 0.59 & -2.80 & -72.29 & 0.61 & -2.88 \\
\hline & & -72.14 & 0. & -2.88 & -72.03 & 0. & -2.94 & -72.26 & 0.58 & -3.10 & -72.19 & 0.35 & -2.99 \\
\hline $\mathrm{TO}_{11}$ & $: 0$ & -71.46 & 0.50 & -2.73 & -71.72 & 0.70 & -2.79 & -71.83 & 0.54 & -2.80 & -71.65 & 0.66 & -2.50 \\
\hline $\mathrm{TO}_{12}$ & & -72.02 & 0.66 & -3.04 & -72.62 & 0.5 & -2.98 & $\begin{array}{l}-72.19 \\
\end{array}$ & $\begin{array}{l}-0.10 \\
\end{array}$ & -2.70 & -72.36 & 0.76 & -2.97 \\
\hline $\mathrm{TO}_{13}$ & & -72.15 & 1. & -3.37 & -72.35 & 0.7 & -3.33 & -72.34 & 1.09 & -2.85 & -72.39 & 0.63 & -2.60 \\
\hline $\mathrm{TO}_{14}$ & $50: 25: 25: 0$ & -72.06 & 0.33 & -2.56 & -72.22 & 0.28 & -2.94 & -72.31 & 1.06 & -3.13 & -72.13 & 0.60 & -2.83 \\
\hline $\mathrm{TO}_{15}$ & & -72.48 & 0.9 & -2.91 & -72 . & 0.2 & -2.5 & -72.70 & 0.4 & -2.94 & -72.76 & 0.40 & -2.71 \\
\hline $\mathrm{TO}_{16}$ & $50: 0: 25: 25$ & -72.13 & 0.96 & -3.11 & -72.42 & 1.17 & -3.07 & -72.69 & 0.67 & -3.42 & -72.65 & 0.63 & -3.10 \\
\hline
\end{tabular}

(TO - Oil Formulation Treatment, CNSL-Cashew nut shell liquid, NSO- Neemseed oil, KSO- Karanjseed oil, BSL-Bhilawan shell liquid)

\section{RESULTS AND DISCUSSION}

\subsection{Viscosity}

Table 3 shows that viscosity of CNSL based termiticides $\mathrm{TO}_{1}, \mathrm{TO}_{2}, \mathrm{TO}_{3}$ and $\mathrm{TO}_{4}$ was $562,89,32$ and $1070 \mathrm{cP}$, at $30{ }^{\circ} \mathrm{C}$, respectively and found decreased to $395,5,4$ and $422 \mathrm{cP}$, respectively with increase in temperature from 30 to $120^{\circ} \mathrm{C}$. The viscosity of $\mathrm{TO}_{4}$ (BSL $100 \%$ ) was found the highest and that of $\mathrm{TO}_{3}$ (KSO 100\%) the lowest among the formulations $\mathrm{TO}_{1}$ to $\mathrm{TO}_{4}$ (pure oils). Viscosity of $\mathrm{TO}_{2}$ (NSO $100 \%$ ) was found decreased by $94.38 \%$ with increase in the temperature from 30 to $120^{\circ} \mathrm{C}$. Asogwa et al. (2007), Djibril et al. (2015), Bobade and Khyade (2012), and Lad et al. (2016) have also observed the similar results of viscosity of CNSL. NSO, KSO and BSL, respectively.

The viscosity of oils was reflected in formulations of termiticides $\mathrm{TO}_{5}$ to $\mathrm{TO}_{16}$ and observed in the range of 296 to $1070 \mathrm{cP}$ in the temperature range of 30 to $120^{\circ} \mathrm{C}$. The viscosity of formulation $\mathrm{TO}_{15}$ was the highest i.e. $838,782,539$ and $495 \mathrm{cP}$ and that of the $\mathrm{TO}_{14}$ the lowest i.e. $311,293,267$ and $234 \mathrm{cP}$ at 30, 60, 90 and $120{ }^{\circ} \mathrm{C}$, respectively among all termiticides. All the oils melt at higher temperatures therefore the viscosity of termiticides was found decreased with increasing temperature from 30 to $120{ }^{\circ} \mathrm{C}$.

\subsection{Refractive Index}

Table 4 shows that among the formulations $\mathrm{TO}_{1}$ to $\mathrm{TO}_{4}$ (pure oils) refractive index of termiticide $\mathrm{TO}_{4}(\mathrm{BSL})$ was the highest i.e. $1.526,1.510,1.504$ and 1.489 and that of $\mathrm{TO}_{3}$ (KSO)the lowest i.e.1.423, 1.411, 1.406 and 1.391 at the temperatures 30 , 60, 90 and $120{ }^{\circ} \mathrm{C}$, respectively. Mukhopadyaya et al. (2010), Djibril et al. (2015), Bhalerao and Sharma (2014), and Lad et al. (2016) have also observed the similar results of Refractive Index of CNSL. NSO, KSO and BSL, respectively.

Refractive index values of oils were reflected in all the termiticides from $\mathrm{TO}_{5}$ toTO $_{16}$. Among termiticides from $\mathrm{TO}_{5}$ to $\mathrm{TO}_{16}$, refractive index of termiticide $\mathrm{TO}_{6}$ was the highest, i.e. 1.510, 1.504, 1.499 and 1.469 and that of $\mathrm{TO}_{14}$ the lowest i.e. 1.479, $1.472,1.465$ and 1.434 , at $30,60,90$ and $120^{\circ} \mathrm{C}$ temperatures, respectively. The refractive index values of all the termiticides were found the highest at $30{ }^{\circ} \mathrm{C}$ and then decreased with increase in the temperature from 30 to $120{ }^{\circ} \mathrm{C}$.

\subsection{Specific Gravity}

Table 5 shows that among the formulations $\mathrm{TO}_{1}$ to $\mathrm{TO}_{4}$ (pure oils), the specific gravity of $\mathrm{TO}_{4}(\mathrm{BSL})$ was the highest i.e. 0.987, 0.985 and 0.983 and that of $\mathrm{TO}_{3}$ (KSO) the lowest i.e. $0.933,0.932$ and 0.932 at the temperatures 30,60 and $90{ }^{\circ} \mathrm{C}$, respectively. Asogwa et al. (2007), Djibril et al. (2015), Bobade and Khyade (2012), and Chopra and Chopra (1956) have also observed the similar results of specific gravity of CNSL. NSO, KSO and BSL, respectively. 
Among termiticides from $\mathrm{TO}_{5}$ to $\mathrm{TO}_{16}$, the specific gravity values of the $\mathrm{TO}_{15}$ were found the highest i.e. $0.970,0.950$, and 0.930 and that of $\mathrm{TO}_{14}$ the lowest i.e.0.940, 0.920 and 0.910 . The specific gravity of all the formulations from $\mathrm{TO}_{1}$ to $\mathrm{TO}_{16}$ was found decreased with increase in the temperature from 30 to $90{ }^{\circ} \mathrm{C}$. With increase in temperature the molecules of oils intermiticides melted due to which its specific gravity was decreased.

\subsection{Colour}

Table 6 shows that the $\mathrm{DL}^{*}\left(+\right.$ whiteness and -blackness) values of all the termiticides $\left(\mathrm{TO}_{5}\right.$ to $\left.\mathrm{TO}_{16}\right)$ were negative showing colour darkness (blackness). The $\mathrm{TO}_{3}$ (KSO) was having the least darkness values (-63.15) among all the oil formulated termiticides and it was seconded by $\mathrm{TO}_{2}$ (NSO) $(-71.26)$ at $30{ }^{\circ} \mathrm{C}$. DL* value was decreased in $\mathrm{TO}_{3}$ (KSO) initially when heated from 30 to $90{ }^{\circ} \mathrm{C}$ and then found increased at $120{ }^{\circ} \mathrm{C}$. Darkness value of $\mathrm{TO}_{1}, \mathrm{TO}_{2}$ and $\mathrm{TO}_{4}$ were increased with increase in temperature from 30 to $120{ }^{\circ} \mathrm{C}$. The $\mathrm{Da}^{*}(+$ redness and - greenness) value of CNSL, NSO and BSL and all oil formulations was less green whereas that of KSO it was 11.65 i.e. reddish. This value of CNSL was observed decreased, of NSO increased and of BSL slightly increased while that of KSO it was increased with increase in temperature from 30 to $120^{\circ} \mathrm{C}$

The $\mathrm{Db}^{*}$ (+yellowness and - blueness) value of CNSL, NSO and BSL and all oil formulated termiticides was bluish whereas that of KSO it was (11.06) yellowish. With increase in temperature from 30 to 120 degree Celsius, the yellowness of KSO was increased (from 11.06 to 19.68), blueness of NSO slightly increased and that of CNSL and BSL blueness was increased. The reflection of colour values of oils is clearly observed in all the oil formulated termiticides with slight differences at the temperatures from 30 to $120{ }^{\circ} \mathrm{C}$. Asogwa et al. (2007), Djibril et al. (2015), Bobade and Khyade (2012), and Chopra and Chopra (1956) have also observed the similar results of colour values of CNSL, NSO, KSO and BSL, respectively.

\section{SUMMARY AND CONCLUSIONS}

Four oils: Cashew nut shell liquid (50, 60, 70, 80, 100), Neemseed oil (10, 15, 20, 25, 100), Karanjseed oil (10, 15, 20, 25, $100)$ and Bhilawan shell liquid $(10,15,20,25,100)$ were used to make CNSL based termiticide. Effect of temperature on viscosity, refractive index, specific gravity and colour of termiticide formulations was studied and conclusions were drawn as below:

- Viscosity refractive index and specific gravity of CNSL based termiticide was found decreased with increase in temperature from 30 to $120^{\circ} \mathrm{C}$.

- Colour of CNSL based termiticide became darker when heated from 30 to $120{ }^{\circ} \mathrm{C}$.

- CNSL based termiticides were oil based therefore the properties of oils were reflected in the termiticide formulations with respect to the temperature.

\section{REFERENCES}

[1] Agrawal A., R. S. Pandey and B. Sharma. 2010. Water Pollution with special reference to pesticide contamination in India. J.Water Reso. and Protection, 2: 432-448.

[2] Behrens, R. 1996. Cashew as an agroforestry crop. Tropical Agriculture (9). MargrafVerlag. Weikersheim, Germany.

[3] CEPC. 2012. About Cashew nut shell liquid statistics. Cashew nut Exports Promotion Council of India.

[4] CEPC. 2015. About Cashew and Cocoa-statistics. Cashew nut Exports Promotion Council of India.

[5] Chang, S. T., S. S. Cheng and S. Y. Wang. 2001. Antitermitic activity of essential oils and components from tawania (Taiwaniacryptomeriodes). J. of Chem. Ecol, 27:717-724.

[6] DACFW. 2016. Directorate of Economics and Statistics. Dept. of Agriculture and Cooperation \& Farmer's Welfare (Hort. Div.). Top ten cashewnut producing states of India: 2012-13. http://eands.dacnet.nic.in/ Publication12-12-13/

[7] EN 118. 2005. European Committee for Standardization. Wood preservatives- determination of toxic values action against Reticulitermes species (European Termites): 17-118.

[8] http://www.cashewinfo.com.

[9] Kamble, K. J., N. J. Thakor, S. P. Sonawane and S. B. Swami. 2016. A review on need of using CNSL, Neemseed oil, Karanj oil and BSL in agriculture for safe environment. IJPARET, 4(9):98-109.

[10] Kamble, K. J., N. J. Thakor, S. P. Sonawane and A. A. Sawant. 2016. Review on need of utilization of biopesticides in agriculture for safe environment. IJETSR; (8) :6-13.

[11] Mahadevappa, H., K. Kempaiah, S. S. Martin and K. S. Girish. 2012. Emerging Roles of Anacardic Acid and Its Derivatives: A Pharmacological Overview. Basic \& Clinical Pharmacology \& Toxicology, Nordic Pharmacological Society.110(2): 122-132. 
[12] Mitchell, J. D. 2002.Termites as pest of crops, forestry, rangeland and structures in Southern Africa and their control, Sociobiology. 40: 4769.

[13] Nagaraja, K. V. and D. Balasubramanian. 2007. Processing and value addition in cashew. National seminar on Research, Development and Marketing of Cashew, $20^{\text {th }}-21^{\text {st }}$ Nov.2007, 89-92.

[14] Thorne, B. L. 1999. Biology of subterranean termites of the genus Reticulitermes in NPMA research report on subterranean termites. National Pest Management Association, Virginia.

[15] Tyman, J. H. P. 1979. Long chain phenols part VIII. Quantitative analysis of the unsaturated constituents of phenolic lipids by thin layer chromatography-mass spectrometry. J. Chromatogra. (136): 289-300.

[16] USEPA. 2000. Finding Alternatives to Persistent Organic Pollutants (Pops) For Termite Management. By members of the UNEP/FAO/Global IPM Facility Expert Group on Termite Biology and Management - established in 2000 to support international activities on Persistent Organic Pollutants (POPs) covered by the Stockholm Convention.

[17] Verma, M., S. Sathyawati and P. Rajendra. 2009. Biological alternatives for termite control: A review. Int. Biodeteriration and Biodegration. 63: 959-972.

[18] Zauba Technologies \& Data Services Pvt. Ltd., 2016).

[19] AOAC. 2000. Association of Official Analytical Chemists. Physicochemical properties of oils and fats.:6-27.

[20] IS. 548(Part 1). 1964. Colour test of oils and fats. Indian Standards for sampling and test for oils and fats.

[21] ISO 2555:1989. Determination of viscosity by Brookfield viscometer 